\title{
Environmentalism as a Political Philosophy for the Anthropocene ${ }^{1}$
}

\author{
doi) https://doi.org/10.21814/anthropocenica.3089
}

\begin{abstract}
Political philosophy stems from the reflexes of crises, risks and threats that society faces. The author understands environmentalism as a tendency of current political philosophy that starts from reflecting the causes and possible effects of the global environmental crisis as one of the most serious threats to the existential preconditions of the current political system and global civilization. Considering the changes in the initial social, technological and environmental conditions of the existence of the economic-political system - which are consequences of the transition from the stable geological-climatic era of the Holocene to the unstable era of the Anthropocene - it is necessary to reconsider the basic premises of the imperatives and conceptual frameworks of the current politicaleconomic system. The founders of modern political thought traced the outlines of the current politicaleconomic system in the philosophical framework, although we can identify some of the basic premises of environmentalism and relevant concepts for the reflection of the current threats and risks in some of their works. The author considers the concept of civil and human rights, the concept of state of nature and the concept of social contract adequate to think about the crisis of the current politicaleconomic system in terms of environmentalism. Then, the author formulates in what meanings these concepts are also valid for the Anthropocene. In conclusion, the author's hypothesis is that the political philosophy of the 21st century must reflect the environmental pre-conditions and the limits of the existence and the forms of the economic-political system and, at the same time, must take into account that any economic and factors influence the quality and sustainability of the environment.
\end{abstract}

Keywords: Political philosophy - Environmentalism - Anthropocene - Human rights - State of nature - Social contract

Resumo: A filosofia política nasce dos reflexos das crises, riscos e ameaças que a sociedade enfrenta. O
autor entende o ambientalismo como uma tendência da filosofia política atual que parte de refletir as
causas e possíveis efeitos da crise ambiental global como uma das mais graves ameaças às pré-condições
existenciais do sistema político atual e da civilização global. Considerando as mudanças nas condições
sociais, tecnológicas e ambientais iniciais de existência do sistema político-económico - que são
consequências da transição da era geológico-climática estável do Holoceno para a era instável do
Antropoceno - é necessário reconsiderar as premissas básicas dos imperativos e marcos conceituais do
atual sistema político-económico. Os fundadores do pensamento político moderno traçaram os
contornos do atual sistema político-económico no quadro filosófico, embora possamos identificar
algumas das premissas básicas do ambientalismo e conceitos relevantes para a reflexão das ameaças e

${ }^{1}$ This article is an English extended version of the original paper "Environmentalizmus ako politická pilozofia pre 21. storočie" published in 2018 in Filozofia, 73(1): pp. 1-13. It is also part of VEGA project1/0291/18 Historic-philosophical analysis of environmental thinking, research on its influences on ethical, legal and political thinking and its social response. 
riscos atuais em algumas de suas obras. $\mathrm{O}$ autor considera o conceito de direitos civis e humanos, o conceito de estado de natureza e o conceito de contrato social adequados para pensar a crise do atual sistema político-económico em termos de ambientalismo. Em seguida, o autor formula em que sentido esses conceitos também são válidos para o Antropoceno. Em conclusão, a hipótese do autor é que a filosofia política do século XXI deve refletir as pré-condições ambientais e os limites da existência e das formas do sistema político-económico e, ao mesmo tempo, deve levar em conta que qualquer econômicos e fatores influenciam a qualidade e sustentabilidade do meio ambiente.

Palavras-chave: Filosofia política - Ambientalismo - Antropoceno - Direitos humanos - Estado de natureza - Contrato social

\section{Introduction}

The subject of political philosophy is to examine the assumptions, possibilities and objectives of politics as well as forms of political establishment, or more precisely forms of the political in general. Political philosophy can therefore be understood not only as the description, analysis and criticism of the political system and its institutions, but also as a normative theory, i.e., the effort to conceive an ideal or at least a desirable state the realization of which society can strive for. The image of an ideal society thus outlined or, on the contrary, the image of an original state of nature is then a criterion that allows an assessment of the current social reality.

Political philosophy also envisions structures to justify power and distribute resources, as well as structures of legitimate coercion and punishment. However, part of the political philosophy is also the effort to identify and reflect the threats and risks faced by society and the subsequent formulation of principles, imperatives and concepts. The implementation of the latter, for example, in social, political or legal form, are essential for institutions and institutes to be able to prevent, or at least to mitigate, possible consequences of the identified threats and risks. According to F. Novosád, political philosophies actually are primarily born as reflections of the crisis periods, risks and threats (Novosád, 2013, pp. 14-16).

\section{Threats, Crises and Risks of Global Civilization}

What, then, are the crises and threats that contemporary political philosophy must reflect on? The development of technologies, especially those of communication and 


\section{Environmentalism as a Political Philosophy for the Anthropocene}

transport, allowed the emergence of a truly global civilization for the first time in history ${ }^{2}$. We can also legitimately speak of global civilization for the first time in history, because the current state of technology allows more than half of the world's population to live in cities $^{3}$.

The source of many threats and risks is that there are people on Earth today as never before in the history of humankind, and social differences have never been greater and have never grown more rapidly than in recent years ${ }^{4}$. From a socio-political point of view, it is the fourth industrial revolution that, because of digitization and robotization, does destroys more jobs than it creates.

Although constitutional democracies remain formally in the political organization of society, in reality, the actual political-economic system is rather a mixture of national and transnational oligarchic power relations. We have never had such destructive power as today's weapons of mass destruction.

Humanity exceeds many limits of sustainability, that is, its production and consumption transcend the possibilities of available resources and the capacities of the planetary ecosystem to metabolize waste and pollution inevitably generated in the existing system of production and distribution of goods and services, or, if you prefer, that are associated with industrialization and urbanism ${ }^{5}$.

\footnotetext{
${ }^{2}$ Globalization is mainly the result of the development of science and technology. Making production, transportation and communications more efficient today leads to the need to make markets leave the limits of the territorial State, putting pressure on the creation of a global market. Politics embedded in a territorial state mainly just catches these processes up, but certainly it cannot regulate or direct them. In the best case, it can mitigate their most significant social and environmental impacts on the territory of the State. We can speak of global civilization primarily on the technological level and on the level of the risks resulting from industrial technologies, far from the political and social levels. It can be said that, for the first time in human history, it has been achieved, at least partially, to implement a demand for universalization, which, according to Patočka, is an internal objective of all civilization (Patočka, 1996, p. 245). Precisely this aspect points to the fundamental difference between the current situation and everything that humanity has faced in its historical development.

${ }^{3}$ According to the UN, 54\% of the world population currently lives in cities and, if nothing changes in the urbanization process, two thirds of humanity will live in urban agglomerations by 2050. Even in the middle of the last century, only less than one third of humanity lived in the cities.

${ }^{4}$ At the beginning of 2016 , the 62 richest people in the world owned properties with an estimated value equivalent to that of the poorest half of the world population, that is, 3.6 billion people (Oxfam 2016). In early 2017, this equivalence was made with only 8 people. In many countries of the world, owners of multinational companies, as well as the domestic oligarchy, have managed to enact legislation to prevent the payment of most taxes, as well as the inheritance tax, which traditionally reduced the intergenerational increase in inequality (Bivona 2016). A recent report showed that the year 2018 continued the growth trend of the richest and the reduction of wealth for the poorest. Twenty-six people controlled as much wealth as 3.8 billion people who comprise half the world's population, compared with forty-three people the previous year (Oxfam 2019). In fact, a global oligarchy with the privileges and riches that medieval nobility or absolutist rulers did not seem to be emerging. From a political point of view, it is basically a question of reversing the outcome of most of the revolutions that led to the emergence of modern civil society and the rule of law.

${ }^{5}$ Massive urbanization goes hand in hand with industrialization, while urbanization would be impossible without the industrialization of agro-production. These processes intensified after the Second World War. Especially in the Global
} 


\section{Richard St'ahel}

The most significant consequences of these phenomena include the stratospheric ozone depletion, the change in the planetary hydrosphere and atmosphere chemical composition, the global climate changes ${ }^{6}$, and because of this, the greatest extinction of animal and plant species since the extinction of dinosaurs. All that to the extent that humanity actually caused the end of the geological-climatic period of the Holocene Epoch and the emergence of the new period, the Anthropocene ${ }^{7}$.

However, our life expectations and consumer demands have never been higher than in recent years. This means that we live in an unsustainable, literally self-destructive way, which undermines the preconditions for civilized life and the organization of humanity. The current political-economic system is, therefore, unsustainable in its three components: economic, social and environmental ${ }^{8}$.

At the same time, it also means that, in order to reflect and analyze these threats, the more to avoid them, most existing philosophical, political, legal and economic concepts are hardly applicable. They emerged as a reflection of the problems of relatively small and closed societies that face, from the current point of view, risks and threats that are easy to manage. Therefore, we live in a world that is in deep crisis, with some of its aspects already in a state of disaster, and irreversible devastation.

\section{Environmentalism as a Direction of Political Philosophy}

In this context, environmentalism can be seen as the direction of contemporary political philosophy that is based on the reflection of the causes and possible consequences

\footnotetext{
South, where the processes have been and are accompanied by exponential population growth. They literally caused billions of people to move from rural areas to growing agglomerations and slums in their suburbs, where millions of people often live without access to water, sewage and infrastructure. Slovakia is a country that has had a similar experience, since intense industrialization and urbanization did not begin before the middle of the last century and have not yet ended.

${ }^{6}$ Climate change is by no means the only manifestation of the global environmental crisis. The pollution of the atmosphere, rivers and oceans, as well as the contamination of the soils by products of industrial activities, chemical compounds and materials such as plastics, are so extensive and intense that in many places on the planet they are already so evident that they are perceived naturally and without the aid of measuring devices. The extent of deforestation or devastation of traditional areas of commercially interesting marine fish by industrial fishing also spreads. The rate of disappearance of species of animals and plants is alarming, which occurs as a result of hunting and mainly the expansion of urbanized areas and agro-production, to the detriment of nature.

${ }^{7}$ The Anthropocene is supposedly a new geological and climatic era, caused by the impact of human activity on Earth's system (Steffen et al., 2011; Steffen et al., 2015). For a philosophical approach to the concept, see Angus (2016) and Davies (2016).

${ }^{8}$ For a critical analysis of this situation, see (Hohoš 2016).
} 


\section{Environmentalism as a Political Philosophy for the Anthropocene}

of the global environmental crisis as one of the most serious threats to the preconditions of existence of the current economic-political scenario, the system and global civilization in general. It is based on the recognition that collective human activities directly undermine or remove environmental preconditions for the existence of civilization. Thus, in contemporary conceptions, environmentalism problematizes mainly the unseen existential dependence of the individual and the social and political institutions of the state of the environment, and points out that the state of the environment adequate for the emergence and maintenance of civilization is not a matter of course.

Environmentalism is based on the recognition that factors such as climate stability, biodiversity or the chemical composition of the planet's atmosphere, hydrosphere and soil, together with the growing negative impacts of human activities on the environment, are essential and irreplaceable public resources and assets at the same time. These factors necessarily attract the attention of political thought and politics itself, since they are not only the object of power struggles, but also, in many cases, literally desperate struggles by entire communities or even states for simple survival.

In part, environmentalism is an effort to understand the philosophical, social and political-economic initiatives and processes involved in the emergence of the current crisis, as well as to outline the concept of a sustainable economic and political organization of society that could overcome the current unsustainable state of things. In the words of the initiator of the Nitrian School of Critical Environmentalism, J. Kučírek, environmentalism «must be able to solve the problem of the responsibility of man and society for the state of the environment on both environmental and social levels that are interconnected» (Kučírek 1998, 3)9.

The environmentalism thus understood reflects the mutual conditionality of the trends of social, economic, political and environmental crisis of global industrial civilization, whose mutual reinforcement represents an existential threat not only to the level of civilized development already achieved, but also to humanity as a biological species. As a result, environmentalism must also answer to one of the key questions that, according to F. Novosád, is posed by current social and political thinking: «How to legitimize political, economic and technical power in a globalizing world, since traditional legitimacy methods fail?» (Novosád 2013, 1) ${ }^{10}$. They fail, not least mainly because of the

\footnotetext{
${ }^{9}$ Orig.: «musí dokázat' vyriešit’ problém zodpovednosti človeka a spoločnosti za stav životného prostredia v oboch vzájomne prepojených rovinách - environmentálnej i sociálnej».

${ }^{10}$ Orig.: «Ako legitimovat' v globalizujúcom svete politickú, ekonomickú a technickú moc, ked’že tradičné metódy legitimovania zlyhávajú?».
} 


\section{Richard St'ahel}

real possibility of self-destruction that is a paradoxical consequence of the human development of the past.

\section{Possibility of Self-destruction as an Existential Threat}

The possibility of humanity's self-destruction is a relatively new threat from the historical point of view. The philosophical reflection around it was a reaction to humanity's entry into the nuclear era in the middle of the last century. Environmentalism can also be understood as an extension of the reflection on the problem related to the possibility of humanity's self-destruction, analyzed, among others, by K. Jaspers in the 1950s. In his work, Die Atombombe und die Zukunft des Menschen (Jaspers 1957), Jaspers addresses the possibility of humanity's self-destruction in a global nuclear conflict. He says that this possibility fundamentally changes the substance and possibilities of politics, or even the very political conscience of humanity.

The threat to destroy humanity and all its life on the planet in the global nuclear conflict has not disappeared; however, it seems to be more manageable ${ }^{11}$ at present than the possibility of humanity's self-destruction as a result of the continuation of "ordinary" life or "development" according to the imperatives that constitute the current economic and political system ${ }^{12}$. Social and environmental devastation, in this case, is not the main objective of human action, but mainly the by-product ${ }^{13}$ of the current methods of production and consumption. Therefore, it is less clear and less obvious than weapons of mass destruction. These are generally well known for the fact that their use serves the

\footnotetext{
${ }^{11}$ It has been more than several decades since all the powers pledged not to test nuclear weapons in the atmosphere, in the oceans or in the universe, or at least in Earth's orbit, and this treaty is also respected by the states that did not join the Treaty on the Non-Proliferation of Nuclear Weapons.

${ }^{12} \mathrm{As}$ J. Kučírek stated in his founding monograph of Slovak environmental philosophy - Ekofilozofia včera, dnes a zajtra [Ecophilosophy yesterday, today and tomorrow], 1st ed. 1995 -: «Today, more than the threat of nuclear war, a social bomb ticking threatens the world and human society. The detonator is detained by human misery that is the result of deepening inequalities within and between countries. Behind numerous civil wars, which act as ethnic or religious wars abroad, poverty and hunger» (Orig.: «Viac ako hrozba nukleárnej vojny dnes ohrozuje svet a l'udskú spoločnost' ,tikot sociálnej bomby‘. Rozbuškou je bieda, ktorá je plodom prehlbujúcej sa nerovnosti vnútri štátov i medzi nimi. Bieda a hlad sa skrývajú za početnými občianskymi vojnami, ktoré navonok vystupujú ako vojny etnické či náboženské») (Kučírek, 2008, p. 88).

${ }^{13}$ For example, thousands of different types of pesticides, herbicides, insecticides and other agrochemicals are used mainly to increase agro-production, so as not to cause soil contamination and contamination of ground and surface water. Likewise, the main purpose of using Freon was not to weaken the Earth's ozone layer, nor did the expansion of fossil-based energy generation technologies occur in order to cause climate change, etc.
} 


\section{Environmentalism as a Political Philosophy for the Anthropocene}

primary purpose of destroying and devastating all living and non-living environments in the affected territory.

In addition, the consequences of using weapons of mass destruction would be immediate, but the consequences of the gradual destruction of living conditions as a result of industrialization and urbanization, that is, as a by-product of rising living standards, are slow, literally crawling and almost imperceptible by the senses. The cause and effect of these phenomena are so far apart in time and space that they mostly represent inaccessible objects of human understanding, unless there is a deep scientific preparation. In other words, only a few people associate flying on vacation to an exotic destination or buying tropical fruits with the idea of destroying their own preconditions for life on the planet, and that tourist or buyer will hardly admit that he is committing an environmental crime against at least future generations.

This situation of inability to look at the real extent of the consequences of daily activities and at the same time its fatality in the synthesis of the activities of all individuals that constitute today's humanity, leads to the question of the need to rethink the premises and preconditions fundamental to the political-economic system of global civilization.

Traditional political thinking did emerge as a reflection of the obvious and immediate threats, e.g. external enemy or internal conflict, or as mirror of a result of ideological, religious or great powers conflicts. However, the nature of today's threats is diametrically different. In fact, the environmental preconditions for an economic and political system itself are threatened, not only from a given territorial state, but also from global civilization as a whole. The threat is not the result of ideological or religious conflicts at this time. On the contrary, it follows from the consensus that there is no other path for development than that proposed by the ideologies of growth, industrialization and consumerism.

A political philosophy appropriate to the threats and challenges of the 21 st century must, therefore, take into account the changes in the initial social, technological and environmental conditions of the existence of the political-economic system, and rethink the premises, imperatives and conceptual frameworks that allow defining and reflecting the political in general. Environmentalism, among other things, addresses the linkage of life strategies, especially economic-political ones, in relation to their environmental options in their realization. The conceptual framework of environmentalism, in particular, questions the significance and functionality of the growth imperative (production, consumption, population, living standards, profits, etc.) and prefers the 


\section{Richard St'ahel}

imperatives of sustainable production, consumption, population or job development, and, above all, its social, political and environmental pre-conditions.

\section{Life Strategies}

In the long run, the sustainability and stability of the economic and political system in a given ecosystem are determined by the ways in which certain societies deal with the imbalance between increasing consumption and the finitude of territorial resources. I refer to these modes as life strategies.

The most fundamentally developed evolutionary life strategy, common to all human societies, is the strategy of production and accumulation of overproduction, as I. Dubnička identified it (Dubnička, 2007a, p. 13). In the search for the possibilities of applying this strategy, humanity has developed several strategies in its history, depending on the specific options: strategy for reducing population growth, strategy for territorial expansion, trade as a way to obtain locally unavailable resources, strategy for using available resources from more efficient way, consumption control strategy, strategy based on the ability to learn from mistakes and hypothetical possibility of space expansion as a continuation of the territorial expansion strategy. ${ }^{14}$ All of these strategies have consequences that are not only environmental, but also social and political, which in turn affect the environment.

Environmentalism points out that socio-political crises, the study of which has traditionally focused on political thinking, arise as a consequence of the continuous increase in the growth rate of the human population. This is linked, on the one hand, to the increase in consumer demand and, on the other, to the deepening of income inequality, or more precisely, of inequalities in access to resources. The stability of global industrial civilization is threatened, therefore, by the deepening of environmental and social-political crisis phenomena, which are complementary and mutually reinforcing ${ }^{15}$.

\footnotetext{
${ }^{14}$ For more about the characteristics of particular life strategies see (St'ahel, 2016c, pp. 117-142).

${ }^{15}$ More in St'ahel (2016a).
} 


\section{Environmentalism as a Political Philosophy for the Anthropocene}

\section{Inadequacy of Environmental Ethics}

A significant part of environmental thinking focuses on the moral reflection of the global environmental crisis. However, due to the continuous environmental devastation, it is necessary to question whether environmental ethics is an adequate tool to overcome the global environmental crisis, especially when considering the time pressure that the global environmental crisis is experiencing.

As already mentioned, in the environmental ethical conception of A. Naess and D. Rothenberg (1989) and H. Jonas (1979), if we take into account the seriousness of the changes necessary to avoid the global environmental collapse and the short time that human civilization has for such a turn, we need to consider the feasibility of environmental liability, especially at the level of political and legal coercion.

As J. Šmajs recalls, ethics is a reflection and criticism of morality that arises from the experiences of all generations. These are spontaneous rules, often intuitively constituted. In addition, morality «effectively functions mainly as nonverbal and unregistered» (Šmajs 2013, 811) $)^{16}$, as part of the tradition in which the individual is socialized. I. Dubnička convincingly demonstrates that morality always legitimates the currently dominant life strategy (Dubnička 2007b). Ethics then repeatedly opposes it as a theory that contradicts the reality of life. More serious, however, is that ethical arguments are capable of influencing the day-to-day conduct of only a small part of the population, especially if these arguments are contrary to the basic imperatives of the politicaleconomic system, or more precisely, to the way the majority of the population meets their daily needs: water, food, clothing and shelter.

I. Dubnička claims that «moral imperatives do not capture the crowd» (Dubnička 2007a, 399 $)^{17}$, especially if a considerable part of the population has been exposed for years to massive indoctrination by the ideologies of growth, industrialization and consumerism, and all this through global mass media ${ }^{18}$. This pressure can hardly be countered by moral arguments. However, in order to face the global environmental crisis, it is essential that the vast majority of the world's population change radically and especially rapidly their behavior, consumption patterns, lifestyles and consumer demands. Therefore, environmental responsibility must be understood as a political and legal category, rather

\footnotetext{
${ }^{16}$ Orig.: «účinne pôsobí predovšetkým ako neverbalizovaná a nezapísaná».

${ }^{17}$ Orig.: «Morálne imperatívy nezachvacujú dav».

${ }^{18}$ More in St'ahel (2016d).
} 


\section{Richard St'ahel}

than a moral and ethical category ${ }^{19}$. Despite the fact that, as J. Šmajs writes, current law has a

tendency to be subdued by capital, it does not once belong to an effective control of "all-competent" morality and becomes an "ideology". As a rule, which should be subjected to morality, it necessarily fails in its function. As a legally permissible procedure, it approves of what damages the future of humanity - looting of the Earth protected by no law (Šmajs, 2015, p. 751) ${ }^{20}$.

It is not only morality that is in crisis, but also the law. In other words, law protects the interests of corporations more than life and its preconditions, or it allows the commodification and commercialization of the basic components of the environment ${ }^{21}$. Contemporary law is thus under the considerable influence of the ideologies of growth, industrialization and consumerism ${ }^{22}$.

\section{Philosophical Basis of Environmentalism in Modern Political Thinking}

Current ideas of morality, politics and law are still based on modern economicpolitical concepts. Some of them may still be useful in describing and analyzing the current crisis, or in searching for possible ways of overcoming it as well. Moreover, some of the basic premises of environmentalism can be identified in them.

We think of Monstesquieu as a precursor to the fundamental premise of environmentalism. In defining what he thinks of the "spirit of the laws", he emphasized

\footnotetext{
${ }^{19}$ Environmental ethics, however, have an important part to play in the justification of environmental law standards, but are ineffective in the process of enforcing compliance with these standards as ethical concepts justifying human rights standards. If an ethically justified human rights discourse fails, and it focuses on current interpersonal relationships, it is very unlikely that the ethical justification for environmental discourse could be successful as it focuses predominantly on relations between future generations and the environment.

${ }^{20}$ Orig.: «tendenciu podriad'ovat' sa kapitálu, vymyká sa kedysi účinnej kontrole “všekompetentnej“ morálky a stáva sa "ideológiou“. Ako regulatív, ktorý by mal podliehat' morálke, nevyhnutne preto zlyháva vo svojej funkcii. Ako právne prípustné konanie totiž schval'uje to, čo poškodzuje l’udskú budúcnost’ - rabovanie zákonmi nechránenej Zeme».

${ }^{21}$ It turns out that the institutionalization of environmental policy, in the form of ministries of the environment or environmental protection agencies, has led to the creation of a legitimation for greater environmental exploration instead of a real change in the paradigm of the relationship between man and nature. There is always a way to grant an exception by allowing mining in a protected area, or to build a hotel and slopes with lighting and sound systems in a national park, or to use water from a lake in a national park to make artificial snow in it. As it is a process based on legislation and authorization granted by a competent public authority, it cannot be contested, although, in fact, it calls into question the meaning of the existence of a national park.

${ }^{22}$ It is not clear whether this situation could be changed by the deeper embedding of legal and political systems in evolutionary ontology, as suggested by Šmajs 2011), and, above all, to what extent such a change is possible, and if so, what is the expected period.
} 


\section{Environmentalism as a Political Philosophy for the Anthropocene}

that laws must be adapted to the physical nature of each country: to cold, hot or moderate climates; to the quality of its soil, its situation and extent; to the main occupation of the natives, whether farmers, hunters or shepherds they must be related to the degree of freedom that the constitution entails; to the religion of the inhabitants, their inclinations, wealth, numbers, commerce, manners and customs (Monstesquieu 1978). In other words, the laws aim to regulate relations between people, but these relations are determined by natural conditions, such as the quality and extent of the soil, the climate and the population.

Political philosophy, however, has not reflected these phenomena until the recent past. In the 19th and 20th centuries, we were quite convinced that technological development had removed all of these determinants. Technological development has succeeded in creating a global industrial civilization, but at the same time, there has been a global environmental crisis, the consequence of which is that many of the premises of political thought in the 19th and 20th centuries are inadequate or even counterproductive in the 21st century.

Monstesquieu and many other political thinkers of the modern era they did not expect that natural conditions, such as climate or soil quality, could change, even because of human activities. However, based on his argument, it can be concluded that if the natural determinants change, the growth rates of the human population decrease or increase, the laws must also change and, finally, the political establishment. Nonetheless, so far a persistent attempt to maintain the status quo has been observed, despite dramatic environmental changes, population growth, declining land size and declining quality.

It must be emphasized that the new political philosophy has created concepts that have made it possible to justify a political arrangement that provides not only safety, but also rights and freedoms. I refer to Montequieu's concept of constitutionally limited government and control of power (though only political power) and Rousseau's concept of people's sovereignty and the existence of inalienable human rights. These concepts emerged within the framework of the philosophical reflection of the contemporary crisis of the political and economic system of the beginning of the New Age, but they did not lose their explanatory or legitimating power. In addition to the concept of civil and human rights, the concept of natural state and the concept of social contract are also relevant to the reflection of the current economic-political system from the point of view of environmentalism. 


\section{Richard St'ahel}

\section{The Concept of Universal Human Rights}

Environmentalism points to the relationship between the concept of human rights and the conditions and opportunities of nature and the landscape where the struggle for human rights and freedom takes place. It is based on the assertion that the crisis of global industrial civilization primarily threatens human rights and freedoms. In the current crisis, not only the biological persistence of humanity as an animal species, but also the preservation of civilization is threatened. The level of scientific and technical knowledge achieved must be maintained and at least maintain the current level of recognition and real availability of human rights and freedoms for the preservation of civilization. If the right to life belongs to the category of fundamental human rights, preconditions for life, not only social but also environmental, including at least breathable air, drinking water and food, must also be the object of political thought.

However, the global environmental crisis threatens the availability of these preconditions, which makes environmental responsibility a fundamental issue in political and legal thinking. The global environmental crisis opens a new perspective for philosophical reflection. The new perspective points to the need to redefine the concept of human rights and increase its importance due to the environmental preconditions for the implementation of human rights and environmental responsibility at the same time ${ }^{23}$. At the same time, the original natural-law-based arguments on the grounds of the origin of human rights should be dropped and replaced with, for example, Axel Honneth's theory of recognition (Honneth 1992).

Honneth understands human rights as a result of real historical struggles and as a result of the mutual recognition of human beings, that is to say,

Like those assertions that human subjects acknowledge one another in order to guarantee them a life that fulfills the necessary conditions of "dignity" or of respect, the focus being that the minimum requirements for the morality of social coexistence are the universal possibilities of human life embrace existence (Honneth, 1994, p. 870) ${ }^{24}$.

\footnotetext{
${ }^{23}$ More in St'ahel (2015).

${ }^{24}$ Orig.: «Wie jene Behauptungen, die menschliche Subjekte einander anerkennen, um ihnen ein Leben zu garantieren, das die notwendigen Bedingungen der "Würde" oder des Respekts erfüllt, wobei im Mittelpunkt steht, dass die Mindestanforderungen an die Moral des sozialen Zusammenlebens die universelle Möglichkeit der menschlichen Existenz umfassen.»
} 


\section{Environmentalism as a Political Philosophy for the Anthropocene}

This is the concept that enables every right to be associated with a specific obligation for those who claim that right, at least with the obligation to grant the same rights as an individual demands for himself to all others as well ${ }^{25}$.

\section{The Concept of the Natural State}

The second concept on which environmentalism can build is the concept of the state of nature, but not in its original meaning of its ahistorical fiction. In particular, I consider Rousseau's understanding of the natural state to be remarkable. Rousseau, however, realizes that the state of nature, that is, in his understanding the state of a small human population and hence, a wealth of resources, is unsustainable simply because of population growth. By his words: «... original state cannot subsist any longer, and the human race would perish if it did not alter its mode of existence» (Rousseau [1762] 2011, p. 163). The state of nature can now be understood as a period in the evolution of humankind, ending with the global environmental crisis, respectively transition from the geological-climatic era of the Holocene to the Anthropocene era. Thus, the state of nature would be a period when a favorable environment could be considered a natural thing, and there is no need to reflect philosophically and legally protect it. Reflecting on the current state of humanity it can be said again that this primary condition can no longer be maintained and that the human race will perish if it does not change its way of existence.

From the current point of view, the natural state can be understood as a situation in which, when considering the principles of the organization of a political society, it was possible to extract sufficient resources from soil, drinking water, breathable air and longterm stability of climatic conditions as a natural thing. The natural state enabled the spontaneous development of humanity, that is, the broad development of technology, the size of human settlements and the extension of the use of natural resources, including the transformation of the landscape into agricultural or urbanized areas. Due to widespread industrialization and urbanism globally, the availability of these aspects of environmental security is obviously lost. The current global environmental crisis shows that the life strategy built on the imperative of growth is reaching its limits. It is obvious that the ability of the planetary ecosystem to continue to reproduce the preconditions of human existence and global industrial civilization is seriously threatened. In other words, a spontaneous

\footnotetext{
${ }^{25}$ More in (St'ahel 2016b).
} 


\section{Richard St'ahel}

social or market order ${ }^{26}$ emerges as self-destructive chaos that is unsustainable in the long run. This can be interpreted in such a way that humanity left the natural state of stable climate and sufficient natural resources and entered a social state in which the protection of water, soil, air and climate must be legislated or even constitutionally incorporated, and therefore, politically not only addressed, but also organized.

\section{The Concept of the Social Contract Theory}

This leads to the third concept, originally from the beginning of modernity, which I consider relevant in the current situation: the concept of social contract. It is kept up to date at the level of the territorial State, where the principle of constitutionality is founded, as well as at the interstate and supra-State level, where interstate treaties are built on it and, in fact, create a new legal reality. Considering the nature of the threats that modern humanity faces, environmentalism faces the challenge of exploring the possibilities of drawing up an environmental social contract that makes it possible to incorporate environmental preconditions and the limits of its existence to national, international and supranational institutions.

Even in this case, it is possible to be inspired by Rousseau's concept of social contract. U. Beck mentioned it when he pointed to the problem of deepening social inequality in the era of climate change (Beck 2010, 173). Also when referring to Rousseau's explanation that «when people want to overcome the state of nature, they are able to discover a path to freedom and identity in the community through a social contract» (Beck [2012] 2013, p. 68) he reflected upon the euro crisis and European integration. Although Rousseau was the theoretician of organizing a small community, according to Beck, it is possible to use it as inspiration for the content and the way to enforce the transnational social contract. Says Beck that «at the beginning of the 21 st century, we are now faced with the task of overcoming national status and reaching a social contract European» (Beck [2012] 2013, p. 68) because today's global threats and risks can no longer be addressed at national and State level.

An example of the relevance of the treaty principle is the Paris Agreement (UN 2015), as well as efforts to conclude trade and investment agreements. These efforts,

\footnotetext{
${ }^{26}$ Spontaneous order is one of the key notions of neo-liberalism by F. A. Hayek. See, e.g., Hayek 1998, 37-52; 231-234).
} 


\section{Environmentalism as a Political Philosophy for the Anthropocene}

together with their consequences on the nature and extent of the political power of territorial states, have the characteristics of the new social contract. In fact, they also represent the abandonment of the Keynesian-Westphalian structure and, likewise, the abandonment of the limited extent of democratic representation and democratic control provided by this structure as well. Unlike the Paris Agreement, whose operation is based solely on volunteering, trade and investment agreements establish procedures to enforce their obligations, for example, in the form of arbitral tribunals. However, for contracts to address global environmental and social risks to be effective, it will be necessary to develop arguments that justify and legitimize recovery procedures.

\section{Conclusion}

In the current ongoing crisis, it turns out that the way we actually live modern life remains extremely unsustainable. The philosophical reflection on this phenomenon of crisis and its causes shows that the philosophical concepts that justify the institutions and imperatives of industrial civilization must be considered as the causes of the crisis, since most of them have evident growth and the necessary resources. However, on the other hand, the political, social and state institutions thus conceived can only fulfill their roles in the society of surplus, respectively in the society of sufficient resources to allow growth to continue. Despite this, it seems that the period of sufficient resources to produce overproduction and long-term growth is over.

Philosophy adequate to the risks and threats that the Anthropocene represents for civilization must be, at the same time, political philosophy and environmental philosophy. The global nature of the Anthropocene's environmental and social threats also means that consideration of the appropriate political, legal and institutional structure of an industrial society must go beyond the territorial state. The relevant political philosophy in the 21 st century must reflect the environmental pre-conditions and the limits of existence, as well as the forms of the political-economic system, taking into account that any economic and social activities affect the quality and sustainability of the environment. This means that the calculation of the possible consequences of any intended policy must include not only economic and social, but also environmental costs and consequences.

From a philosophical point of view, the Anthropocene is a situation in which humanity can no longer assume an environment favorable to the existence of civilization as a state of nature, but must assume responsibility for the planetary environment and 


\section{Richard St'ahel}

must actively seek to maintain it. Thus, as a result of its activities, humanity has reached adulthood, which means that it must leave its careless age and take responsibility for the consequences of all its activities and bear the responsibility of guaranteeing the human future as a species and life on Earth in general.

\section{References}

Angus, I. (2016). Facing the Anthropocene: Fossil capitalism and the crisis of earth system. New York: Monthly Review Press.

Beck, U. (2010). Remapping social inequalities in an age of climate change: for a cosmopolitan renewal of sociology. Global Networks 10(2): pp. 165-181.

Beck, U. ([2012] 2013). German Europe. Transl.: R. Livingstone. Cambridge: Polity.

Bivona, R. (2016, September 27). It's Time to Replace the Estate Tax With a Progressive Inheritance Tax. Retrieved from: http://www.truth-out.org/opinion/item/37761-it-stime-to-replace-the-estate-tax-with-a-progressive-inheritance-tax

Davies, J. (2016). The birth of the Anthropocene. Oakland, California: University of California Press.

Dubnička, I. (2007a). Kultúra a environmentálna kríza [Culture and the environmental crisis]. Nitra: UKF v Nitre.

Dubnička, I. (2007b). Mravy, šelmy a vegetariáni [Morals, beasts and vegetarians]. Nitra: UKF v Nitre.

Hayek, F. (1973 [2013]). Law, Legislation and Liberty a New Statement of the Liberal Principles of Justice and Political Economy. London \& New York: Routledge.

Hohoš, L. (2016). A Tentative Scenario of "Sustainable Degrowth Society”. Philosophica Critica, 2(1): pp. 59-64. 


\section{Environmentalism as a Political Philosophy for the Anthropocene}

Honneth, A. (1992). Integrity and Disrespect: Principles of a Conception of Morality Based on the Theory of Recognition. Political Theory, 20(2): pp. 187-201.

Honneth, A. (1994). Universalismus als moralische Falle?: Bedingungen und Grenzen einer Politik der Menschenrechte [Universalismus als moralische Falle?: Bedingungen und Grenzen einer Politik der Menschenrechte]. Merkur, 48(546/547): pp. 867-883.

Jaspers, K. (1957). Die Atombombe und die Zukunft des Menschen [The atomic bomb and the future of humanity]. München/Zürich.

Jonas, H. (1979). Das Prinzip Verantwortung. Versuch einer Ethik für die technologische Zivilisation [The principle of responsibility. An ethics for technological civilization]. Frankfurt/Main: Insel-Verlag.

Kučírek, J. (1998). Politika a ideológia environmentalizmu [Politics and ideology of environmentalism]. Civitas - časopis pre politické a sociálne vedy, 4(14):pp. 2-4.

Kučírek, J. (2008). Ekofilozofia včera, dnes a zajtra [Ecophilosophy yesterday, today and tomorrow]. Nitra: UKF v Nitre.

Monstesquieu, C. (1748). Esprit des lois. Genève: Barrillot \& Fils.

Næss, A. \& Rothenberg, D. (1989). Ecology, community and lifestyle: outline of an ecosophy. Cambridge: Cambridge University Press.

Novosád, F. (2013). O čom sú dejiny sociálnych a politických teórií [What is the history of social and political theories about]. In: F. Novosád \& D. Smreková (eds.), Dejiny sociálneho a politického myslenia [History of Social and Political Thought] (pp. 11-19). Bratislava: Kalligram.

OXFAM (2016, January 18). 62 people own the same as half the world, reveals Oxfam Davos report. Retrieved from: https://www.oxfam.org/en/pressroom/pressreleases/2016-0118/62-people-own-same-half-world-reveals-oxfam-davos-report 


\section{Richard St'ahel}

OXFAM (2017, January 16). Just 8 men own same wealth as half the world. Retrieved from: https://www.oxfam.org/en/pressroom/pressreleases/2017-01-16/just-8-men-own-samewealth-half-world

OXFAM (2019). Public good or private wealth? Oxford: Oxfam.

Patočka, J. (1996). Nadcivilizacie a její vnitřní konflikt [Over-civilization and its internal conflict]. In: J. Patočka, Péče o duši I. Sebrané spisy. Svazek 1 [Care for the soul I: Collected works. Volume 1]. (pp. 243-302). Praha: Oikoymenh.

Rousseau, J.-J. ([1762] 2011). On the Social Contract. In: Jean-Jacques Rousseau: The Basic Political Writings (pp. 155-252). Transl.: D. Cress. Hackett Publishing Company.

Šmajs, J. (2011). Potřebujeme filosofii př ě̌ití? Úvahy o př́rodě, kultuře, ekonomice, práci, poznání a popularizaci vědy [Do we need a philosophy of survival? Reflections on nature, culture, economics, work, knowledge and popularization of sciences]. Brno: Doplněk Masarikova Univerzita.

Šmajs, J. (2013). Proč etika nestačí [Why ethics is not enough]. Filosofický časopis, 61(6): pp. 803-826.

Šmajs, J. (2015). Př́ŕroda - nový subjekt morálky a práva? [Nature - a new subject of morality and law?]. Filosofickýčasopis, 63(5):pp. 749-756.

Steffen, W., Grinevald, J., Crutzen, P., \& McNeill, J. (2011). The Anthropocene: Conceptual and historical perspectives. In Philosophical Transactions of The Royal Society A: Mathematical Physical and Engineering Sciences, 369(1938): pp. 842-867.

Steffen, W., Persson, A., Deutsch, L., Zalasiewicz, J., Williams, M., Richardson, K., Crumley, C., Crutzen, P., Folke, C., Gordon, L., Molina, M., Ramanathan, V., Rockström, J., Scheffer, M., Schellnhuber, H. J., \& Svedin, U. (2011). The anthropocene: from global change to planetary stewardship. Ambio, 40(7), 739-761. 


\section{Environmentalism as a Political Philosophy for the Anthropocene}

Steffen, W., Richardson, K., Rockström, J., Cornell, S. E., Fetzer, I., Bennett, E. M., Biggs, R., Carpenter, S. R., de Vries, W., de Wit, C. A., Folke, C., Gerten, D., Heinke, J., Mace, G. M., Persson, L. M., Ramanathan, V., Reyers, B., \& Sörlin, S. (2015). Sustainability. Planetary boundaries: guiding human development on a changing planet. Science (New York, N.Y.), 347(6223), 1259855.

St'ahel, R. (2015). Environmentálna zodpovednost' a environmentálna bezpečnost' [Environmental responsibility and environmental safety]. Filozofia, 70(1): pp. 1-12.

St'ahel, R. (2016a). Environmental Crisis and Political Revolutions. In: J. Arnasson \& M. Hrubec (Eds.), Social Transformations and Revolutions: Reflections and Analyses (pp. 99-120). Edinburgh: Edinburgh University Press.

St'ahel, R. (2016b). K rozporu v zdôvodnení charakteru a pôvodu l'udských práv [Inconsistency in the justification of the nature and origin of human rights]. In: A. Javorská, L. Kocinová \& S. Wagnerová (eds.), (Meta)filozofia - prax: zborník vedeckých príspevkov [(Meta) philosophy - practice: a collection of scientific papers] (pp. 273-279). Bratislava: SAV..

St’ahel, R. (2016c). Filozofia environmentálnej krízy globálnej priemyselnej civilizácie [Philosophy of the environmental crisis of global industrial civilization]. In: O. Suša, O. \& R. St'ahel, Environmentální devastace a sociální destrukce [Environmental devastation and social destruction]. (pp. 97-225). Praha: Filosofia.

St'ahel, R. (2016b). Climate Change and Social Conflicts. Perspectives on Global Development and Technology, 15(5): pp. 480-496.

UN (2015). Framework Convention on Climate Change (Adoption of the Paris Agreement). Retrieved from: https://unfccc.int/resource/docs/2015/cop21/eng/lo9r01.pdf 


\section{Richard St'ahel}

Para citar:

St'ahel, R. (2020). Environmentalism as a Political Philosophy of the Anthropocene. Anthropocenica. Revista de Estudos do Antropoceno e Ecocrítica 1:pp. 3-22. 